\title{
Distribution of Anopheles in Vietnam, with particular attention to malaria vectors of the Anopheles minimus complex Claire Garros ${ }^{1,2}$, Cam Van Nguyen ${ }^{3}$, Ho Dinh Trung ${ }^{4}$, Wim Van Bortel ${ }^{5}$, Marc Coosemans ${ }^{5,6}$ and Sylvie Manguin*1
}

\begin{abstract}
Address: ${ }^{1}$ Institute of Research for Development (IRD), Centre of Biology and Management of Populations, Campus International de Baillarguet, CS 30 016, 34988 Montferrier sur Lez, France, 2Université Catholique de Louvain, Unité d'Ecologie et de Biogéographie, Place Croix du Sud, 4-5, 1348 Louvain-La-Neuve, Belgium, ${ }^{3}$ Institute of Geography, Vietnam Academy of Sciences and Technologies (VAST), 18 Hoang Quoc Viet, Hanoi, Vietnam, ${ }^{4}$ National Institute of Malariology, Parasitology and Entomology (NIMPE), Luong The Vinh street, Tu Liem, Hanoi, Vietnam, ${ }^{5}$ Prince Leopold Institute of Tropical Medicine (ITM), Department of Parasitology, Nationalestraat 155, B-2000 Antwerpen, Belgium and ${ }^{6}$ Department of Biomedical Sciences, Faculty of Pharmaceutical, Veterinary and Biomedical Sciences, University of Antwerp, Belgium
\end{abstract}

Email: Claire Garros - clairegarros@uclouvain.be; Cam Van Nguyen - ngcamvanvn@yahoo.com; Ho Dinh Trung - hodinhtrung@nimpe.vn; Wim Van Bortel - WVBortel@itg.be; Marc Coosemans - MCoosemans@itg.be; Sylvie Manguin* - manguin@mpl.ird.fr

* Corresponding author

Published: II January 2008

Malaria Journal 2008, 7:II doi:10.1 186/1475-2875-7-II
Received: 24 September 2007

Accepted: II January 2008

This article is available from: http://www.malariajournal.com/content/7/I/II

(C) 2008 Garros et al; licensee BioMed Central Ltd.

This is an Open Access article distributed under the terms of the Creative Commons Attribution License (http://creativecommons.org/licenses/by/2.0), which permits unrestricted use, distribution, and reproduction in any medium, provided the original work is properly cited.

\begin{abstract}
Background: The distribution of anopheline mosquitoes in Vietnam was examined, with a particular interest for the two sibling species of the Anopheles minimus complex (Cellia: Myzomyia), An. minimus and Anopheles harrisoni, respectively former species A and C. Because the morphological identification of both sibling species is difficult and may lead to misidentifications, accurate data on their respective distribution are missing. This is of fundamental importance since the two species seem to exhibit differential vectorial capacities for malaria transmission.
\end{abstract}

Methods: Large entomological surveys based on cattle collections and molecular identifications of An. minimus s.l. were carried out in 23 sites throughout northern, central and south-eastern regions of Vietnam.

Results: Based on previous molecular works and our data, the distribution of anopheline species and the relative densities of An. minimus and An. harrisoni were mapped. It is noteworthy that there was a high specific biodiversity at each study site. Anopheles minimus s.l. and Anopheles sinensis were the main anopheline species in the northern region, whereas Anopheles aconitus and Anopheles vagus were the most frequent ones in the central region. The southern limit of An. harrisoni was increased to the latitude of $11^{\circ} \mathrm{N}$. Sympatry between both sibling species has been extended to new provinces.

Conclusion: Malaria transmission is still high in central Vietnam and along bordering countries. Therefore, it is important to know and map the precise distribution of the main and secondary malaria vectors in Vietnam for applying efficient vector control programmes. Moreover, these maps should be regularly updated and linked to environmental characteristics relative to disease epidemiology, and environmental and climatic changes occurring in southeast Asia. 


\section{Background}

The main malaria vector Anopheles minimus s.l. (Myzomyia Series, Funestus Group) is composed of three sibling species, An. minimus (former species A), Anopheles harrisoni (former species C), and An. minimus species E [1]. Anopheles minimus and An. harrisoni can be sympatrically distributed over the southeast Asian mainland whereas species $\mathrm{E}$ is restricted to the Ishigaki Island in the Ryukyu Archipelago, Japan, a malaria free region [2,3]. Because the morphological identification of the two sympatric species is unreliable [4], accurate data on the distribution of An. minimus and An. harrisoni are missing [3]. Morphological misidentifications with the closely related sympatric species, such as Anopheles aconitus, Anopheles pampanai and Anopheles varuna, are common [5,6]. Recently, molecular identification assays have been developed which can be used to shed light on the specific distribution of each sibling species [7-10].

Anopheles minimus s.l. occurs in hilly, forested areas [5]. Northern Vietnam exhibits different types of landscapes ranging from the plains of the Red River to high mountains $(3,143$ meters). The most common larval habitats of
An. minimus s.l. are streams or canals, with slow-running water partially shaded by grassy margins [5]. In central and south-eastern region of Vietnam, both An. minimus s.l. and Anopheles dirus s.l. occur $[3,11]$. The latter is the main malaria vector associated with forests or rubber plantations. Even if malaria epidemics have been hardly reported in northern Vietnam for the past 10 years, central Vietnam is still a high malaria risk area $[12,13]$.

To date, throughout Vietnam, An. minimus was molecularly reported in 17 provinces; and An. harrisoni confirmed in nine provinces (Figure 1, Table 1).

Since these sibling species may exhibit different vectorial capacities $[14,15]$, it is fundamental to know the precise distribution of each species and to infer potential risk zones. Moreover, the southeast Asian region is currently under strong environmental changes that may alter with the vector distribution and malaria epidemiology. Therefore, the overall aim of this work was (1) to define the anopheline biodiversity in Vietnam; (2) to review the literature on molecular records of An. minimus s.l.; (3) to compile a distribution map for the two members of the

Table I: Previous records of An. minimus and An. harrisoni (based on allozyme electrophoresis and molecular identifications)

\begin{tabular}{|c|c|c|c|c|}
\hline Number & Locality & Date of collection & Species & Reference \\
\hline 1 & Ha Giang Pr & March 1999 & both & {$[10]$} \\
\hline 2 & & & Anopheles minimus & \\
\hline 3 & Lao Cai Pr & Feb. 1999 & Anopheles minimus & \\
\hline 4 & & & Anopheles minimus & \\
\hline 5 & Son La $\mathrm{Pr}$ & Oct. 1999 & both & \\
\hline 6 & & & both & \\
\hline 7 & Cao Bang Pr & Nov. 1999 & both & \\
\hline 8 & & & both & \\
\hline 9 & Lang Son $\mathrm{Pr}$ & Apr. 2000 & both & \\
\hline 10 & Hoa Binh Pr & 3-5 surveys in 1999 & both & {$[8,10,18]$} \\
\hline 11 & & & both & {$[10,29]$} \\
\hline 12 & & & Anopheles minimus & \\
\hline 13 & Hanoi $\mathrm{Pr}$ & 10 surveys, years not given & Anopheles minimus & {$[10,18,30]$} \\
\hline 14 & & & Anopheles minimus & \\
\hline 15 & & & Anopheles minimus & \\
\hline 16 & Thanh Hoa Pr & Nov. 1999 & both & {$[10]$} \\
\hline 17 & Nghe $\mathrm{An} \mathrm{Pr}$ & Nov. 1999 & Anopheles minimus & \\
\hline 18 & & & both & \\
\hline 19 & $\mathrm{Ha}$ Tinh $\mathrm{Pr}$ & Nov. 1999 & both & \\
\hline 20 & & & Anopheles minimus & \\
\hline 21 & Binh Dinh Pr & Dried sample & Anopheles minimus & \\
\hline 22 & Gia Lai Pr & June 1999 & Anopheles minimus & \\
\hline 23 & & & Anopheles minimus & \\
\hline 24 & Khanh Hoa Pr & 2001 & both & {$[9,30]$} \\
\hline 25 & Binh Thuan Pr & 4 surveys in 1999 & Anopheles minimus & {$[10,30]$} \\
\hline 26 & & 2 surveys in 1999 & No Anopheles minimus s.l. & \\
\hline 27 & & May 1999 & & \\
\hline 28 & Dong Nai Pr & July 1999 & Anopheles minimus & \\
\hline 29 & Binh Phuoc Pr & 3 surveys in 1999 & Anopheles minimus & \\
\hline 30 & Tay Ninh Pr & May 1999 & Anopheles minimus & \\
\hline
\end{tabular}

$\operatorname{Pr}=$ province. 


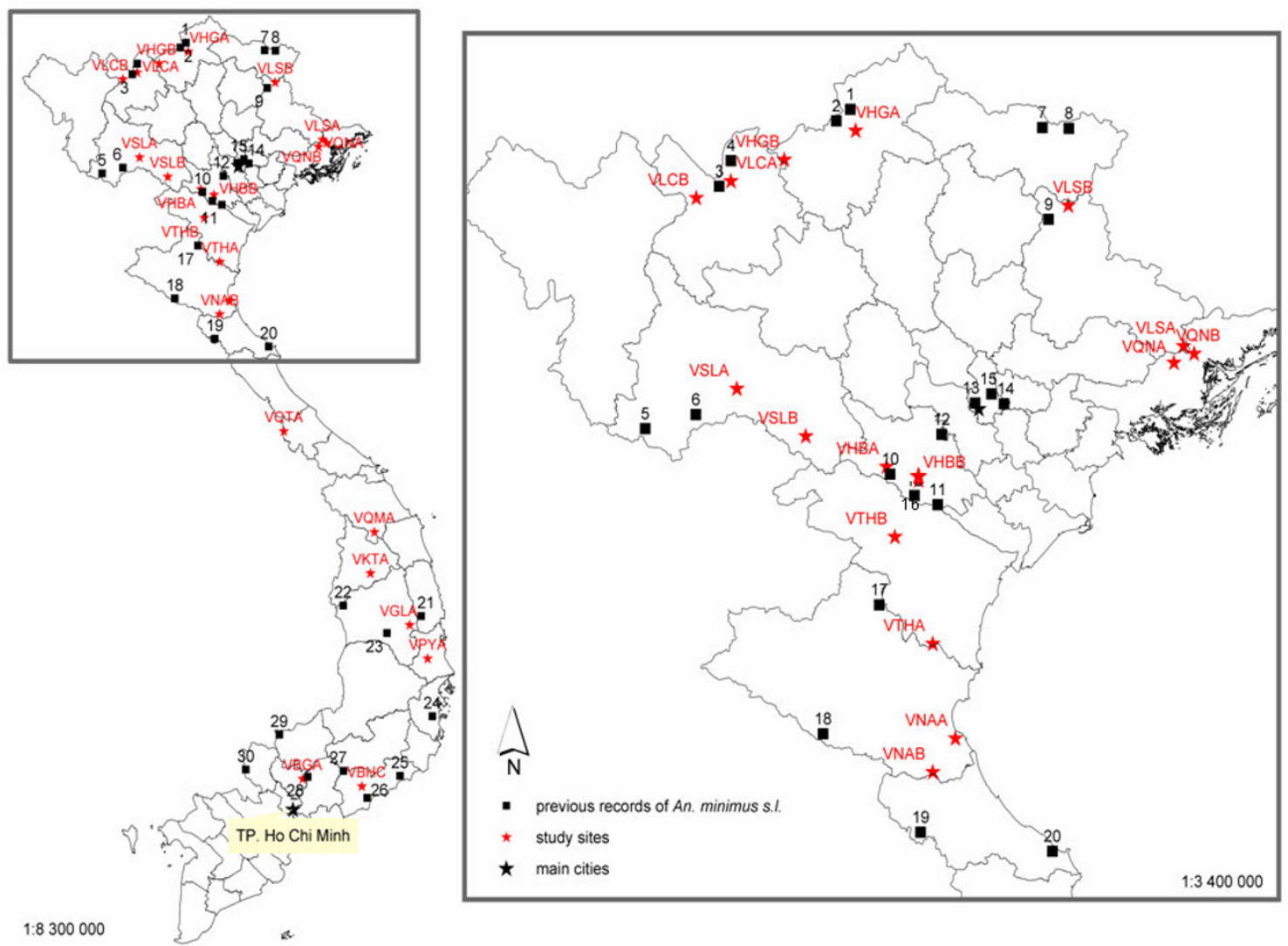

Figure I

Distribution of Anopheles minimus and Anopheles harrisoni in Vietnam based on previous records and the 23 study sites (red dots). Numbers refer to Table I. The close-up on the northern region is for a better reading.

Anopheles minimus complex, based on previous records and 23 new study sites.

\section{Methods}

A total of 23 sites in 15 provinces were selected for mosquito collections in different geographical areas of northern, central and south-eastern Vietnam (Figure 1, red dots, Table 2). Adult mosquitoes were captured on cattle bait once, from October 2003 to November 2004, during a period ranging from 3 to 10 nights (Table 2). One to 5 cattle-sheds were sampled by two collectors from $21 \mathrm{~h}$ to midnight (Table 2). Details on mosquito collections are given in Table 2.

Adult mosquitoes were morphologically identified in the field using the standardized key for the medically important anophelines of southeast Asia [16]. Specimens of An. minimus s.l. were DNA-extracted [17] and identified with an allele specific-PCR (AS-PCR) assay [18]. Primers for An. aconitus, An. pampanai and An. varuna were used in the PCR mix to avoid misidentifications with the sympatric species, An. minimus and An. harrisoni. Positive controls of these five species identified with different molecular assays, were used [7].

Latitude/longitude position and altitude of the sites were measured with a Global Positioning System (GARMIN Etrex, Hampshire, UK) (Table 2). Mosquito densities (number of adult mosquitoes/cattle shed/night for each species) were incorporated into a database linked to the Geographic Information System package ArcView (ESRI, Redlands, California).

\section{Results and Discussion}

This work provides updated distribution of anopheline biodiversity in Vietnam (Figure 2) and deepens and extends our knowledge on the distribution of An. minimus, An. harrisoni and associated anopheline species (Figures 1 and 3). Molecular records available in the literature were included to draw a complete distribution map of the Minimus complex.

The choice of collecting mosquitoes on cattle bait was intentional to have a good representation of the anophe- 
Table 2: Description of the 23 study sites $(\mathrm{Pr}=$ province $) . \mathbf{N}=$ number of cattle-sheds sampled.

\begin{tabular}{|c|c|c|c|c|c|c|}
\hline Village code* & Locality & GPS position & Altitude (meters) & Date of Collection & $\mathrm{N}$ & Type of landscape \\
\hline VSLA & Son La Pr & $21^{\circ} 08^{\prime} 58.3 \mathrm{~N}, 104^{\circ} 07^{\prime} 32.0 \mathrm{E}$ & 644 & 4-13 Apr. 2003 & 3 & $\begin{array}{l}\text { Uplands of Northern Vietnam } \\
(400-900 \mathrm{~m})\end{array}$ \\
\hline VSLB & & $20^{\circ} 50^{\prime} 05.2 \mathrm{~N}, 104^{\circ} 36^{\prime} 06.5 \mathrm{E}$ & 799 & 15-22 Apr. 2003 & 3 & \\
\hline VHBA & Hoa Binh Pr & $20^{\circ} 38^{\prime}$ II.IN, $105^{\circ} 09^{\prime} 58.4 \mathrm{E}$ & 418 & 2-9 May 2003 & 3 & Landscape with limestone peaks \\
\hline VHBB & & $20^{\circ} 32^{\prime} 4.5 \mathrm{~N}, 105^{\circ} 23^{\prime} 17.8 \mathrm{E}$ & 241 & II-18 May 2003 & 3 & $\begin{array}{c}\text { Hilly areas }(100-400 \mathrm{~m}) \text { and valleys of } \\
\text { Northern Vietnam, with isolated high } \\
\text { hills }\end{array}$ \\
\hline VHGA & Ha Giang Pr & $22^{\circ} 50^{\prime} \mid 1.7 \mathrm{~N}, 104^{\circ} 56^{\prime} 55.4 \mathrm{E}$ & 84 & 4-6 Nov. 2003 & 2 & \\
\hline VHGB & & $22^{\circ} 38^{\prime} 45.5 \mathrm{~N}, 104^{\circ} 27^{\prime} 25.8 \mathrm{E}$ & 689 & I2-19 Nov.2003 & 3 & Uplands (400-900 m) \\
\hline VQNA & Quanh Ninh Pr & $21^{\circ} 19^{\prime} 12.8 \mathrm{~N}, 107^{\circ} 09^{\prime} 42.3 \mathrm{E}$ & 40 & 28 Apr.-3 May 2004 & 3 & $\begin{array}{l}\text { Hilly areas of Northern Vietnam } \\
(50-100 \mathrm{~m}) \text { with isolated low hills }\end{array}$ \\
\hline VQNB & & $21^{\circ} 22^{\prime} 39.0 \mathrm{~N}, 107^{\circ} 17^{\prime} 57.4 \mathrm{E}$ & 22 & 8-15 May 2004 & 3 & \\
\hline VTHA & Thanh Hoa Pr & $19^{\circ} 28^{\prime} 48.0 \mathrm{~N}, 105^{\circ} 29^{\prime} \mid \mathrm{I} .2 \mathrm{E}$ & 138 & 29 Apr.-9 May 2004 & 2 & $\begin{array}{l}\text { Hilly areas }(100-400 \mathrm{~m}) \text { and valleys of } \\
\text { Central Vietnam, with isolated high hills }\end{array}$ \\
\hline VTHB & & $20^{\circ} 10^{\prime} 50.7 \mathrm{~N}, 105^{\circ} 13^{\prime} 09.0 \mathrm{E}$ & 87 & |5-2| May 2004 & 2 & $\begin{array}{l}\text { Coastal plain (less than } 100 \mathrm{~m} \text { ) and } \\
\text { valleys of Central Vietnam, with } \\
\text { isolated high hills }\end{array}$ \\
\hline VNAA & Nghe An Pr & $18^{\circ} 5 I^{\prime} \mid 6.7 \mathrm{~N}, 105^{\circ} 38^{\prime} 35.5 \mathrm{E}$ & 14 & 3-10 May 2004 & 2 & \\
\hline VNAB & & $18^{\circ} 38^{\prime} 21.4 \mathrm{~N}, 105^{\circ} 29^{\prime} 07.9 \mathrm{E}$ & 67 & 16-2I May 2004 & 3 & $\begin{array}{l}\text { Hilly areas }(100-400 \mathrm{~m}) \text { and valleys of } \\
\text { Central Vietnam, with isolated high hills }\end{array}$ \\
\hline VLSA & Lang Son Pr & $21^{\circ} 25^{\prime} 18.0 \mathrm{~N}, 107^{\circ} 13^{\prime} 42.6 \mathrm{E}$ & 121 & 4-10 June 2004 & 2 & $\begin{array}{c}\text { Hilly areas }(100-400 \mathrm{~m}) \text { and valleys, } \\
\text { with isolated high hills }\end{array}$ \\
\hline VLSB & & $22^{\circ} 20^{\prime} 32.1 \mathrm{~N}, 106^{\circ} 25^{\prime} 19.6 \mathrm{E}$ & 365 & $|2-2|$ June 2004 & 3 & \\
\hline VLCA & Lao Cai Pr & $22^{\circ} 30^{\prime} 08.3 \mathrm{~N}, 104^{\circ} 05^{\prime} 03.3 \mathrm{E}$ & 147 & 10-12 June 2004 & 3 & \\
\hline VLCB & & $22^{\circ} 23^{\prime} 42.2 \mathrm{~N}, 103^{\circ} 50^{\prime} 35.1 \mathrm{E}$ & 1,256 & 23-30 June 2004 & 3 & Medium mountains $(1,200-2,500 \mathrm{~m})$ \\
\hline VBHC & Binh Thuan Pr & $11^{\circ} 05^{\prime} 17.6 \mathrm{~N}, 107^{\circ} 53^{\prime} 43.7 \mathrm{E}$ & NA & 24 Sep. -12 Oct. 2004 & 5 & $\begin{array}{l}\text { Hilly areas }(100-400 \mathrm{~m}) \text { and valleys of } \\
\text { Central Vietnam, with isolated high hills }\end{array}$ \\
\hline VQMA & Quang Nam Pr & $15^{\circ} 09^{\prime} 14.9 \mathrm{~N}, 108^{\circ} 06^{\prime} 25.5 \mathrm{E}$ & NA & 30 Sep. -5 Oct 2004 & I & \\
\hline VGLA & Gia Lai Pr & $13^{\circ} 39^{\prime} 59.4 \mathrm{~N}, 108^{\circ} 42^{\prime} 24 . \mathrm{IE}$ & NA & I-19 Oct. 2004 & 3 & Uplands (400-900 m) \\
\hline VQTA & Quang Tri Pr & $16^{\circ} 45^{\prime} 54.4 \mathrm{~N}, 106^{\circ} 34^{\prime} 14.6 \mathrm{E}$ & NA & I8-28 Oct. 2004 & 2 & \\
\hline VPYA & Phu Yen Pr & $13^{\circ} 07^{\prime} 42.9 \mathrm{~N}, 109^{\circ} 00^{\prime} 31.0 \mathrm{E}$ & NA & $2|-3|$ Oct. 2004 & 4 & $\begin{array}{l}\text { Hilly areas }(100-400 \mathrm{~m}) \text { and valleys of } \\
\text { Central Vietnam, with isolated high hills }\end{array}$ \\
\hline VKTA & Kon Tum $\mathrm{Pr}$ & $14^{\circ} 29^{\prime} 27.5 \mathrm{~N}, 108^{\circ} 02^{\prime} 30.3 \mathrm{E}$ & NA & 27 Oct.-2 Nov. 2004 & 3 & Low altitude (less than $900 \mathrm{~m}$ ) \\
\hline VBGA & Binh Duong $\mathrm{Pr}$ & $11^{\circ} 12^{\prime} 19.5 \mathrm{~N}, 106^{\circ} 53^{\prime} 39.6 \mathrm{E}$ & NA & I2-20 Nov. 2004 & 1 & $\begin{array}{l}\text { High plains bordering the North of the } \\
\text { Mekong delta (less than } 100 \mathrm{~m} \text { ) }\end{array}$ \\
\hline
\end{tabular}

* Village code stands for $\mathrm{V}=$ Vietnam, second and third letters for initials of the province, $\mathrm{A}, \mathrm{B}$ or $\mathrm{C}=$ village.

line fauna throughout Vietnam and not to focus only on malaria vectors. In addition, studies have shown the zoophilic behaviour of known malaria vectors $[15,19]$, which makes this collection method the most appropriate for our objective of mapping the anopheline biodiversity in Vietnam. The results illustrated and reinforced that oriental Anopheles are clearly opportunistic mosquitoes with trophic behaviour heterogeneities as previously found in Vietnam [15] and Thailand [20]. It is noteworthy that no individuals of An. pampanai and An. varuna were identified, although both species have already been recorded in central Vietnam (Khanh Hoa and Binh Thuan Provinces $[7,8])$. One assumption could be that An. pampanai and An. varuna, being so closely related to An. aconitus [5], may have been morphologically misidentified as An. aconitus [5]. The An. aconitus populations, identified on morphological characters only, need to be screened with the ASPCR assay in order to avoid any potential misidentifications. If this assumption is confirmed, the density of $A n$. aconitus would have been over-estimated. The results showed that An. minimus s.l., main malaria vector, and secondary malaria vectors such as An. aconitus, are present throughout Vietnam independently of the type of landscapes, except the costal fringe where other malaria vectors are present.

Based on morphological identifications, a total of 19 anopheline species were collected and identified throughout the northern to south-eastern regions of Vietnam (Table 3) out of the 38 taxa of the Indochina fauna [12].

A total of 706 An. minimus s.l. were DNA-extracted and identified as An. minimus or An. harrisoni for all the sites, except five sites with samples not available and three sites with no An. minimus s.l. populations (Table 3). Only two misidentifications in the An. minimus samples (two An. minimus s.l instead of two An. aconitus) were noticed for the VSLA site (northern region). No sites with An. harrisoni only were found neither for the northern region nor the central one (Figure 3). Interestingly enough, sites where 


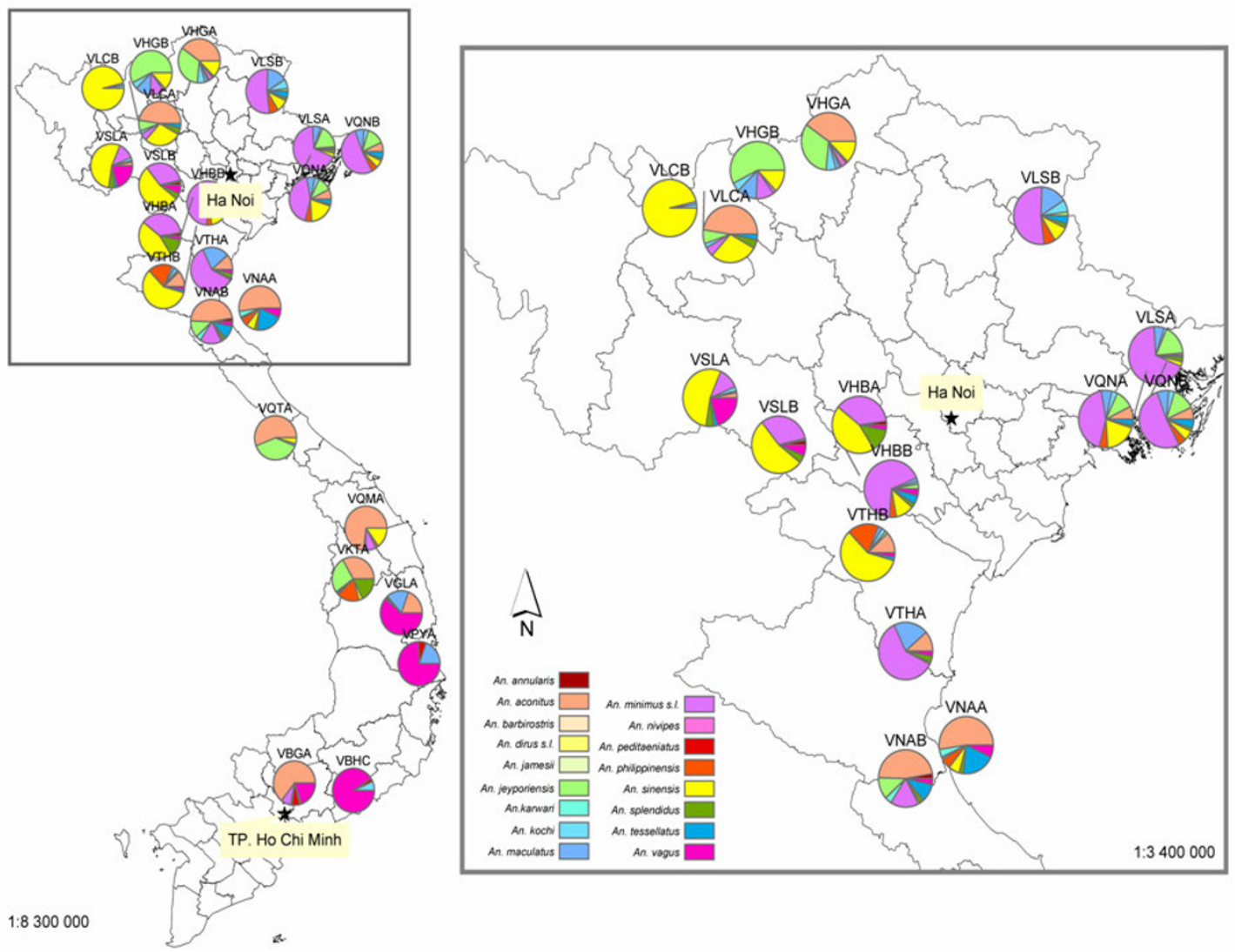

Figure 2

Map of the relative densities for each anopheline taxon. The close-up on northern region is for a better reading.

An. harrisoni was dominant, An. minimus was often rare. This is the case in two sites in the Son La Province (northern region). This may reflect a competition between these two sibling species which needs to be further investigated. Molecular species identifications were intentionally not carried out for the Dirus and Maculatus complexes, because the Minimus complex was targeted. Recently, Obsomer et al. [11] published an updated review and clarified the distribution of the Dirus complex in southeast Asia.

\section{Northern Vietnam}

Anopheles minimus s.l. and An. sinensis were the main species collected on cattle over the northern region, followed by An. aconitus and An. jeyporiensis (Figure 2). Two sites were negative for An. minimus s.l. (VNAA and VLCB) and one site (VTHB) presented a very low density (Table 3, Figure 2).

The VNAA village is surrounded by pine plantations. The overall number of anophelines collected was low (204 specimens during six nights) and An. minimus s.l. was not present during the time of our survey. The absence of $A n$. minimus s.l. in the VLCB site is likely explained by the high altitude $(1,256 \mathrm{~m})$. Actually in Vietnam, An. minimus s.l. is commonly found at an altitude ranging from 200 to 800 meters and becomes quite rare at altitudes above 1,500 meters $[5,21]$. The low density of An. minimus s.l. in the VTHB site (only three specimens) may be due to very recent agricultural changes linked to modified irrigation systems that may have disturbed the mosquito larval habitats, phenomenon also observed in Thailand [22] and India [23]. The main species in this site were An. sinensis and Anopheles philippinensis, the latter species having much lower densities in all the other sites and is known to occur in agricultural areas [24].

Five sites out of 15 were negative for An. harrisoni (VHBB, VHGA, VNAA, VNAB, VLCB), whereas An. minimus was present in 13 out of 15 surveyed sites. Anopheles harrisoni was the predominant species of the complex in three sites only, two in the Son La Province (VSLA and VSLB), and one in the Lang Son Province (VLSB). 


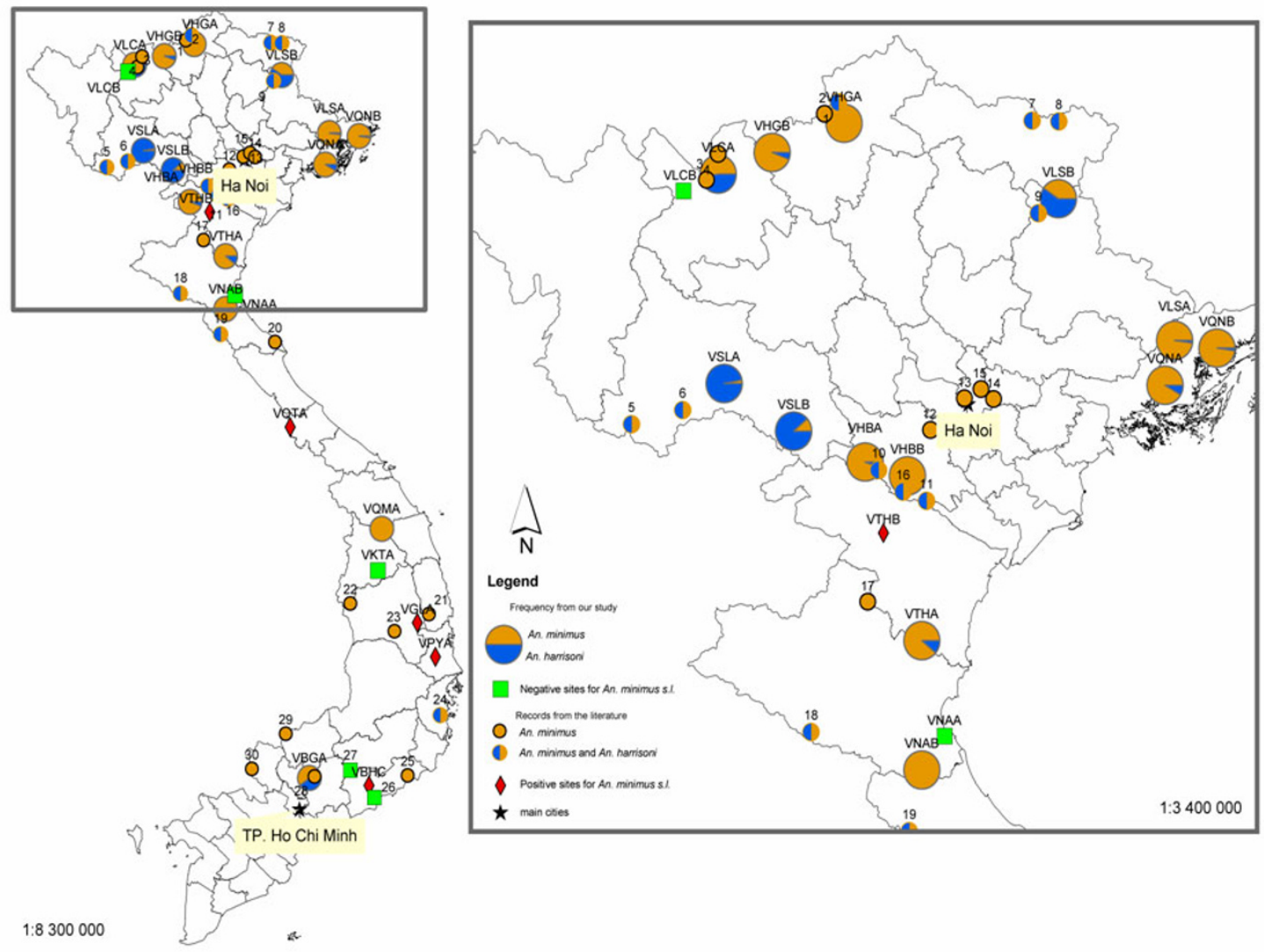

Figure 3

Distribution of the two sibling species of the Minimus Complex based on records obtained from this study and from the literature. Numbers refer to Table I. The close-up on northern region is for a better reading.

Regarding the distribution reported in previous studies in northern Vietnam (Figure 1), the results bring new insights on the distribution of the Minimus complex. For the first time, the anopheline composition of the extreme eastern area of the northern region was analysed and the sympatry of the two species has been reported in the three new study sites in Quanh Ninh (VQNA, VQNB) and Lang Son (VLSA) Provinces. More westwards, Phuc et al.[10] reported An. minimus only in their two sites in Lao Cai Province. However, one site (VLCA) was found positive for both sibling species in this province. Further south, the two sites VTHA and VNAB showed two different situations in the hilly areas of Thanh Hoa and Nghe An Provinces, respectively sympatric populations and An. minimus only.

In northern Vietnam, malaria is relatively well controlled but still occurs at the border of China and Laos [12]. However, the presence of main vectors, such as An. minimus and possibly An. harrisoni, represents a permanent threat for the resurgence of malaria in this region with the move- ment of infected human populations from endemic areas such as central Vietnam and bordering countries.

\section{Central and south-eastern Vietnam}

Anopheles aconitus and An. vagus were the most frequent species in these regions (Table 3, Figure 2). Anopheles dirus s.l. was found in low densities in two sites only (VGLA and VPYA) (Table 3, Figure 2). It occurs typically in forests and forested fringes, either natural or man-made, such as rubber plantations where its contribution to malaria transmission is quite important in central Vietnam and throughout southeast Asia [11]. It is a highly anthropophilic mosquito [11] which explains the low densities collected on cattle during our surveys (Table 3 ).

One site (VKTA) was negative for An. minimus s.l. and four sites among the seven had low densities ranging between one and six specimens (Table 3, Figure 2). Anopheles harrisoni was recently found in Khanh Hoa Province [9] (site 24, Figure 1) and as recorded previously in three northern sites, the densities of this species are now more important 


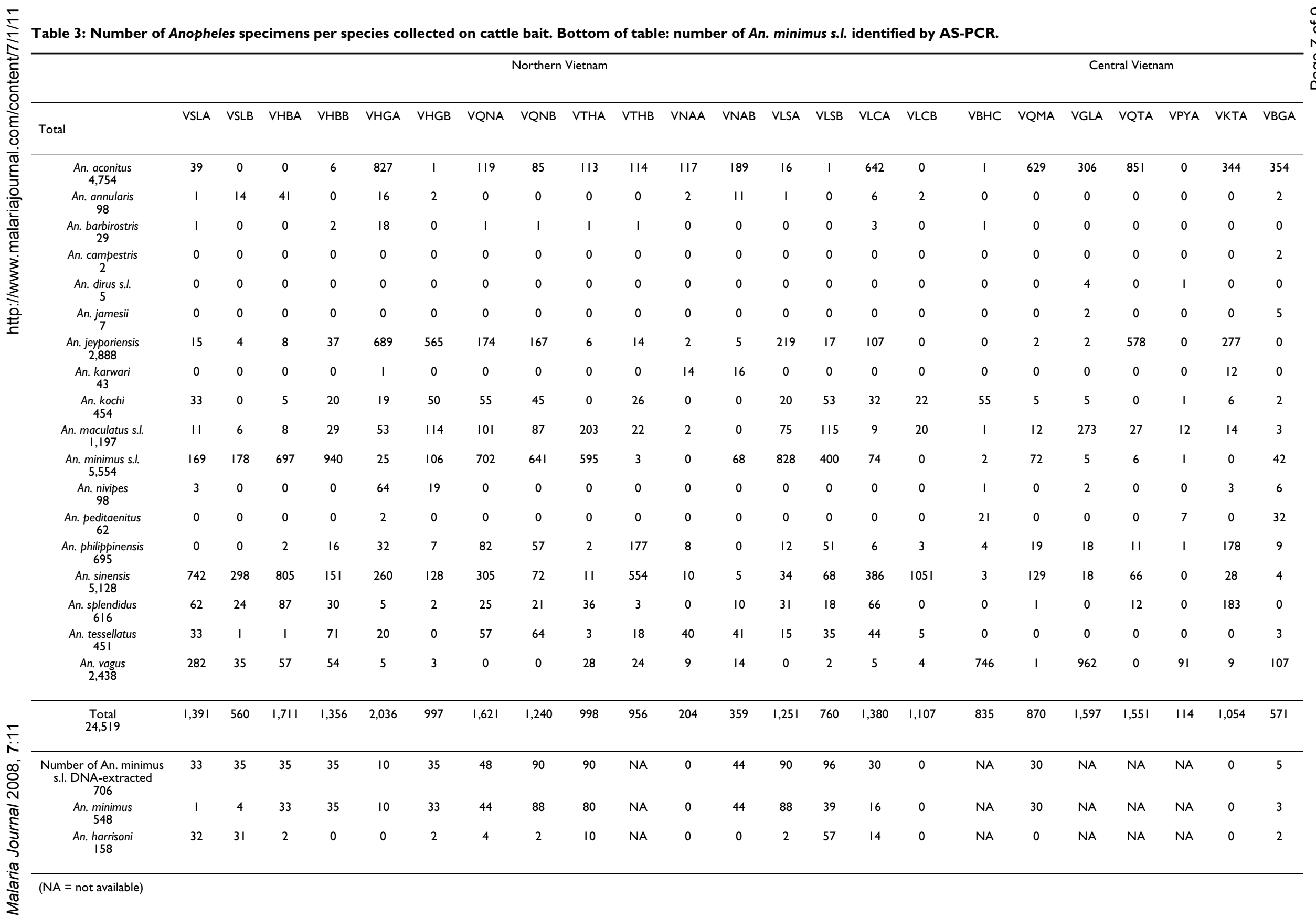


than those of An. minimus which was reportedly the dominant species until 1999 [9]. This was the first record of this species in central Vietnam at a latitude of $12^{\circ} \mathrm{N}$ [9]. These results increased the southern limit of An. harrisoni to Binh Duong Province (VBGA), located in south-eastern Vietnam, at a latitude of $11^{\circ} \mathrm{N}$, less than $100 \mathrm{~km}$ northwest of Ho Chi Minh City. This is a new site where An. minimus and An. harrisoni are sympatric.

Anopheles aconitus, the Maculatus complex and An. vagus were collected in high densities in central Vietnam (Table $3)$. Anopheles maculatus s.l. is thought to be one of the main vector in the Oriental region [25-27], and An. aconitus is considered a secondary vector in Bangladesh, India, Indonesia (Java) and Thailand $[22,25,28,29]$.

\section{Conclusion}

Based on cattle collections, An. minimus s.l. and An. sinensis were the main species in northern Vietnam, whereas $A n$. aconitus and An. vagus were dominant in central Vietnam. Anopheles minimus and An. harrisoni of the Minimus complex are present over the northern, central and southeastern Vietnam, down to latitude $11^{\circ} \mathrm{N}$. Malaria transmission is still high in central Vietnam and along bordering countries. Future entomological surveys in the surrounding countries and, on a larger scale throughout southeast Asia, are required to molecularly identify the different members of the Minimus and Aconitus Subgroups to clarify the precise distributions of each member and to improve vector control strategies.

Compiling distribution maps based on large sample collections is not an academic exercise. Knowing precise and accurate geographic distributions of vector species is an important prerequisite for: (1) an adequate choice of zones where vector control actions should focus, (2) a better selection of future study sites for entomologists working on secondary or local vector species, (3) studies on anopheline biodiversity relating to environmental and climatic changes, (4) analyses of landscape-species associations, and (5) modelling malaria risk maps or comparison of predictive ecological maps with field observations.

Since malaria transmission still occurs in central Vietnam and population movement from the centre to the north are important, vector control measures must be maintained. In addition, entomological, epidemiological and climatic data need to be integrated into a Geographic Information System to follow the future trends of the disease and to assess the malaria risk zones. These maps should be regularly updated and linked to environmental characteristics of disease epidemiology relating to environmental and climatic changes occurring in southeast Asia.

\section{Competing interests}

The author(s) declare that they have no competing interests.

\section{Authors' contributions}

CG participated in the spatial and data collections in northern Vietnam, carried out the molecular identification of the Minimus samples, analysed and interpreted the data, and drafted the manuscript. CVN coordinated the spatial data collections in northern and central Vietnam and made substantial intellectual contributions to the paper. THD coordinated all the entomological surveys and contributed to the content of the paper. MC (coordinator of the Malvecasia project) and SM initiated the study and revised the paper critically for important intellectual content. All authors read and approved the final manuscript.

\section{Acknowledgements}

The authors have no conflict of interest concerning the work reported in this paper. This study was made possible with the precious help of the NIMPE staff (National Institute of Malariology, Parasitology and Entomology, Hanoi, Vietnam) that provided mosquito samples from several sites throughout Vietnam. This work was supported by the INCO European Malvecasia research project ( ${ }^{\circ}$ IC4-CT-2002-1004I).

\section{References}

I. Harbach RE: The classification of genus Anopheles (Diptera: Culicidae): a working hypothesis of phylogenetic relationships. Bull Entomol Res 2004, 94:537-553.

2. Somboon P, Walton C, Sharpe RG, Higa Y, Tuno N, Tsuda Y, Takagi M: Evidence for a new sibling species of Anopheles minimus from the Ryukyu Archipelago, Japan. J Am Mosq Control Assoc 2001, 17:98-113.

3. Garros C, Van Bortel W, Di Trung Ho, Coosemans M, Manguin S: Review of the Minimus Complex of Anopheles, main malaria vector in Southeast Asia: from taxonomic issues to vector control strategies. Trop Med Int Health 2006, I I: I02-I I4.

4. Sungvornyothin S, Garros C, Chareonviriyaphap T, Manguin S: How reliable is the humeral pale spot for identification of cryptic species of the Minimus Complex? J Am Mosq Control Assoc 2006, 22: $|85-9|$.

5. Harrison BA: The Myzomyia Series of Anopheles (Cellia) in Thailand, with emphasis on intra-interspecific variations (Diptera: Culicidae). Medical entomology studies - XIII. Contr Am Entomol Inst 1980, 17: I- 195.

6. Van Bortel W, Harbach RE, Trung HD, Roelants P, Backeljau T, Coosemans M: Confirmation of Anopheles varuna in Vietnam, previously misidentified and mistargeted as the malaria vector Anopheles minimus. Am J Trop Med Hyg 200I, 65:729-32.

7. Van Bortel W, Trung HD, Roelants P, Harbach RE, Backeljau T, Coosemans M: Molecular identification of Anopheles minimus s.l. beyond distinguishing the members of the species complex. Insect Mol Biol 2000, 9:335-340.

8. Kengne P, Trung HD, Baimai V, Coosemans M, Manguin S: A multiplex PCR-based method derived from random amplified polymorphic DNA (RAPD) markers for the identification of species of the Anopheles minimus group in Southeast Asia. Insect Mol Biol 2001, 10:427-435.

9. Garros C, Marchand RP, Quang Nguyen Tuyen, Hai Nguyen Son, Manguin S: First record of Anopheles minimus $C$ and significant decrease of Anopheles minimus $\mathbf{A}$ in central Vietnam. J Am Mosq Control Assoc 2005, 21 : 139-1 43.

10. Phuc HK, Ball AJ, Son L, Hanh NV, Tu ND, Lien NG, Verardi A, Townson H: Multiplex PCR assay for malaria vector Anopheles minimus and four related species in the Myzomyia Series from Southeast Asia. Med Vet Entomol 2003, 17:423-428. 
II. Obsomer V, Defourny P, Coosemans M: The Anopheles dirus complex: spatial distribution and environmental drivers. Malar J 2007, 6:.

12. NIMPE. Annual Report of the National Malaria Control Programme in Vietnam 2006.

13. Erhart A, Ngo DT, Phan VK, Ta TT, Van Overmeir C, Speybroeck N, Obsomer V, Le XH, Le KT, Coosemans M, d'Alessandro U: Epidemiology of forest malaria in central Vietnam: a large scale cross-sectional survey. Malar J 2005, 4:58.

14. Trung HD, Van Bortel W, Sochantha T, Keokenchanh K, Quang NT, Cong LD, Coosemans M: Malaria transmission and major malaria vectors in different geographical areas of Southeast Asia. Trop Med Int Health 2004, 9:230-237.

15. Trung HD, Van Bortel W, Sochanta T, Keokenchanh K, Briet O, Coosemans M: Behavioural heterogeneity of Anopheles species in ecologically different localities in Southeast Asia: A challenge for vector control. Trop Med Int Health 2005, 10:25I-262.

16. NIMPE. In Keys to the Anopheles in Vietnam (Adults-Pupae-Larvae) Department of Entomology, Institute of Malarialogy, Parasitology and Entomology, Hanoi, Vietnam; 1987.

17. Linton YM, Harbach RE, Moh S Chang, Anthony TG, Matusop A: Morphological and molecular identity of Anopheles (Cellia) sundaicus (Diptera: Culicidae), the nominotypical member of a malaria vector species complex in Southeast Asia. Syst Entomol 200I, 26:357-366.

18. Garros C, Koekemoer LL, Coetzee M, Coosemans M, Manguin S: A single multiplex assay to identify major malaria vectors within the African Anopheles funestus and the Oriental Anopheles minimus Groups. Am J Trop Med Hyg 2004, 70:583-590.

19. Van Bortel W, Trung HD, Sochantha T, Keokenchan K, Roelants P, Backeljau T, Coosemans M: Eco-ethological heterogeneity of the members of the Anopheles minimus complex (Diptera: Culicidae) in Southeast Asia and its consequences for vector control. J Med Entomol 2004, 4I:366-374.

20. Sungvornyothin S, Muenvorn V, Garros C, Manguin S, Prabaripai A, Bangs MJ, Chareonviriyaphap T: Trophic behavior and biting activity of the two sibling species of the Anopheles minimus complex in western Thailand. J Vector Ecology 2006, 31:252-26I.

21. Duc NH, Huu HV: Distribution of Anopheles minimus in Northern Vietnam. Ann Scientific Works 1973:134- 40.

22. Chareonviriyaphap T, Bangs MJ, Ratanatham S: Status of malaria in Thailand. Southeast Asian J Trop Med Public Health 2000, 3 I :225-237.

23. Jambulingam P, Sahu SS, Manonmani A: Reappearance of Anopheles minimus in Singhbum hills of East-Central India. Acta Trop 2005, 96:31-35.

24. Scanlon JE, Reid JA, Cheong WH: Ecology of Anopheles vectors of malaria in the Oriental region. Cahiers ORSTOM 1968, 6:237-246.

25. Mouchet J, Carnevale P, Coosemans M, Julvez J, Manguin S, RichardLenoble D, Sircoulon J: Biodiversité du paludisme dans le monde. John Libbey Eurotext, Paris, France; 2004.

26. Rahman WA, Abu Hassan A, Adanan CR: Seasonality of Anopheles aconitus mosquitoes, a secondary vector of malaria, in an endemic village near the Malaysia-Thailand border. Acta Trop 1993, 55:263-265.

27. Rahman WA, Che'Rus A, Ahmad AH: Malaria and Anopheles mosquitoes in Malaysia. Southeast Asian J Trop Med Public Health 1997, 28:599-605.

28. Kirnowardoyo S: Status of Anopheles malaria vectors in Indonesia. Southeast Asian J Trop Med Public Health 1985, 16:129-132.

29. Maheswary NP, Habib MA, Elias M: Incrimination of Anopheles aconitus Donitz as a vector of epidemic malaria in Bangladesh. Southeast Asian J Trop Med Public Health 1992, 23:798-80I.

30. Van Bortel W, Trung HD, Manh ND, Roelants P, Verle P, Coosemans M: Identification of two species within the Anopheles minimus complex in northern Vietnam and their behavioural divergences. Trop Med Int Health 1999, 4:257-265.

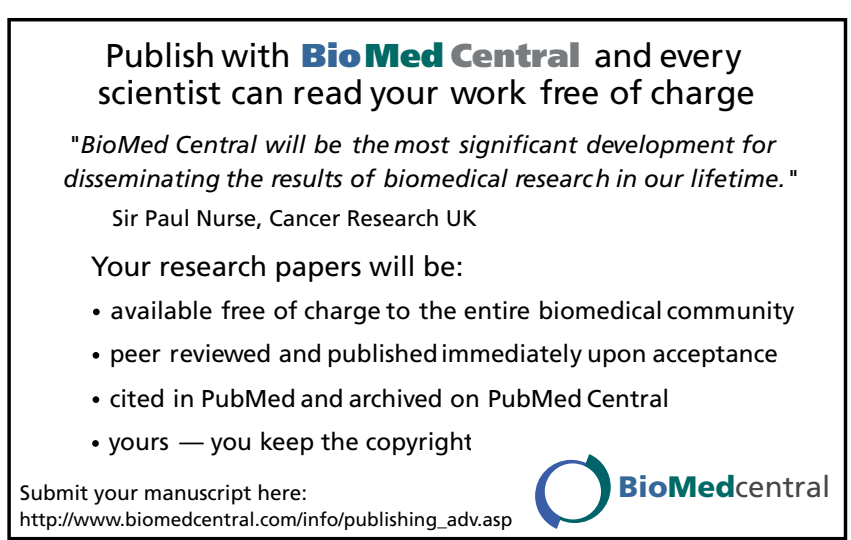

